\title{
EFFECTS OF ENZYMES SUPPLEMENTATION ON DIGESTIBILITY AND ENERGY UTILIZATIONS OF BROILERS DIETS WITH DIFFERENT METABOLIZABLE ENERGY LEVEL
}

\section{Glamočić, M. Polovinski-Horvatović, M. Ivković, D. Beuković, S. Bjedov}

Faculty of Agriculture, 8 Dositeja Obradovića Square., 21000, Novi Sad, Republic of Serbia Corresponding author: glamocic@gmail.com

Invited paper

Abstract: In this $3 \times 2$ factorial design trial with three different levels of metabolizable energy $(13.4,13.00,12.6 \mathrm{MJ} / \mathrm{kg}$ ), with and without exogenous enzymes (nutrition density was reduced by introducing sunflower meal in different percentage to diet $(0,8$ и $16 \%))$, the goal was to investigate the effects of exogenous enzymes Roxazyme G2G (cellulase (endo-1,4-( $\beta$-glucanase), $\beta$ glucanase (endo-1,3(4)- $\beta$-glucanase) and xylanase (endo-1,4- $\beta$ xylanase)) on digestibility and energy utilization. Effects of enzymes were most visible in diet with $13.00 \mathrm{MJ} / \mathrm{kg}$ and $12.6 \mathrm{MJ} / \mathrm{kg}$ while this effect was unnoticed in the group with $13.4 \mathrm{MJ} / \mathrm{kg}$. Reducing of ME caused the decrease in digestibility and metabolizability (ME/GE). The results suggest that exogenous enzymes, used in this trial, increase digestibility of crude proteins, NDF, hemicelluloses and ash $(p<0.05)$, but the effects were most evident in diets with the reduced level of metabolizable energy.

Key words: broilers, exogenous enzymes, digestibility,

\section{Introduction}

Early beginnings of introducing exogenous enzymes in nutrition of monogastrics animals are from the end of 1940. The first researcher who reported about a positive effect of exogenous enzymes in nutrition with high level of fiber was Hastings 1946, until then scientists believed that introducing exogenous enzymes in nutrition of non ruminant animal wouldn't have any effect after passing upper part of digestive tract. Since then, the concept regarding the usage of exogenous enzymes has been changed significantly, from the usage of only single type of enzyme to the usage of multiple enzymes products which act on divers group of nutrients. 
Sunflower meal which can most often be found on our market contains $33 \%$ crude protein, and high level of cellulose $(21 \%$ is the legal limit (Sl. list SRJ", br. 20/2000 i 38/2001)). Cell wall of sunflower seed contains considerable amount of $\beta$-glucans, xilana, arabans, pectins, and various other oligosaccharides, this polysaccharides cause the increase of intestinal viscosity and consequently the depression in productivity of poultry (Senkoylu, 1999).

The reduction of metabolizable energy level linearly decreases digestibility of DM and AME (Zhou, 2009). The effect of the usage of exogenous enzyme in some studies is more visible when metabolizable energy level is reduced (Zhou, 2008).

Enzymes have clearly been demonstrated to increase the digestibility of poorly digested diets to a much greater extent than well digested diets (Classen et al., 1995; Scott et al., 1998). A researcher concluded that chicks benefited more from enzymes at a younger age (Olukosi et al., 2007), but the effect of age was not observed in another trail (Fuente, 1995). The effect of added enzymes is mediated through gut flora, whereas in young animals which have poorly developed digestive system, and not fully develop gut flora the effect is probably more direct (Bedford, 2001; Bedford, 2000).

The goal of this trail was to investigate effects of added exogenous enzymes Roxazyme G2G (cellulase (endo-1,4-( $\beta$-glucanase), $\beta$-glucanase (endo$1,3(4)$ - $\beta$-glucanase) and xylanase (endo-1,4- $\beta$ xylanase)) on digestibility of nutrients and energy utilization of broilers diet variably in metabolic energy, of 2831 days old male Ross 308 broilers. Nutrition density was reduce by introducing sunflower meal with $33 \% \mathrm{CP}$ in diet in different percent $(0,8,16 \%)$.

\section{Materials and Methods}

A metabolism trail was used to estimate the nutrients digestibility (organic mater, crude protein, fat, crude ash, NDF, ADF, hemicelluloses, crud fiber) and metabolizability (ME/GE). Chicks were reared in the masonry broiler house from 1 to 24 days of age, and than transferred to metabolic cages. A total 96, 24 day old Ross 308 hybrids were allocated randomly to 6 dietary treatments with 4 replicates per treatments, and 4 birds per replicates (three level of metabolic energy: 13.40; $13.00 ; 12.60 \mathrm{MJ} / \mathrm{kg}$; with or without of an enzyme complex). The total experimental period was seven days, with four days for bird adaptation to the experimental diets and cages, and the remaining three days for excreta collection, which was carried out once a day. The methods used to determine digestibility of nutrients and metabolic energy were total collection method and partial collection method (one percent of Celit was added to the diet for this purpose). Collected excreta samples were placed in plastic bags, duly identified, weighed and stored in a freezer on $-20^{\circ} \mathrm{C}$. At the end of the experimental period, feed intake and total 
amount of produced excreta were determined. Samples were thawed at environment temperature. Excreta were homogenized and dried in a forcedventilation oven at $55^{\circ} \mathrm{C}$ for 72 hours. Dried excreta samples were ground and submitted to the Animal Nutrition Lab at Department of Animal Science, Faculty of Agriculture, Novi Sad. AIA (Celite) was analyzed according to the procedure described by Vogtmann et al. (1975). Crude protein, crude fiber, crude fat were analyzed using Wende method, while NDF, ADF and hemicelluloses (NDF-ADF) were analyzed using the procedure of Van Soest (Van Soest, 1983).

Data were analyzed by GLM using StatSoft software (STATISTICA 8, 2009), to determine the effect of enzymes addition, diet type and interaction between this two factors. Linear contrast of enzymes effect (i.e. with vs. without enzymes addition) within each diet was made. The results are considered significant when $\mathrm{P}<0.05$.

Table 1. Composition and nutrient analyses of experimental diets

\begin{tabular}{|l|c|c|c|}
\hline Ingridients & Diet 1 & Diet 2 & Diet 3 \\
\hline Corn & 62.21 & 59.86 & 57.54 \\
\hline Soybean meal & 13.64 & 7.96 & 2.25 \\
\hline Full-fat soybeans & 20.00 & 20.00 & 20.00 \\
\hline Sunflower meal & 0.00 & 8.00 & 16.00 \\
\hline L-lysine HCL & 0.00 & 0.07 & 0.16 \\
\hline DL-Methionine & 0.18 & 0.16 & 0.15 \\
\hline Monocalcium phosphate & 1.36 & 1.38 & 1.39 \\
\hline Salt & 0.43 & 0.42 & 0.40 \\
\hline Limestone & 1.17 & 1.15 & 1.12 \\
\hline Premix & 1.00 & 1.0 & 1.00 \\
\hline Calculated analyses & \multicolumn{5}{|l|}{} \\
\hline Crude protein, \% & 19.00 & 19.00 & 19.00 \\
\hline Crude fat & 6.12 & 6.08 & 6.05 \\
\hline Crude fiber & 3.57 & 4.82 & 6.07 \\
\hline ME, MJ/kg & 13.40 & 13.00 & 12.60 \\
\hline Lysine, \% & 1.01 & 1.00 & 1.00 \\
\hline Methionine, \% & 0.49 & 0.49 & 0.49 \\
\hline
\end{tabular}

\section{Results and Discussion}

Metabolizability (ME/GE) and digestibility of nutrients determined by two methods (total and partial excreta collection method) are shown in tables 2 and 3. Enzyme complex had a significant effect $(\mathrm{P}<0.05)$ on digestibility of NDF, hemicelluloses, and ash determined by both methods. The metabolizability (ME/GE) decreases with the reduction of energy density of diet. Enzyme 
supplementation enhanced metabolizability but the effect of enzyme supplementation wasn't statistically significant $(\mathrm{P}>0.05)$.

The present study demonstrated that the addition of the multicarbohydrase supplement of cell wall degrading enzymes did not improve digestibility of nutrients and energy in diet with not reduced metabolizable energy level. These results are consistant with some other trail conducted so far on the effect of exogenous enzymes in diet with normal nutrition density based on corn and soybean (Dourado et al., 2009; Saleh, 2005). Moreover some trail conducted on the diet in which sunflower meal was concluded up to $20 \%$, with normal nutrition density, also didn't give any improvements in digestibility of nutrients or AME (Tavernari, 20008). The effect of multicarbohydrase supplementation is closely connected with ME level by some researchers (Zhou, 2008). The most advanced effect of enzymes in this trail was on diets with reduced nutrition density (13.00 and $12.6 \mathrm{MJ} / \mathrm{kg})$, but most often statistically significant differences between diets with and without enzymes complex were in $13 \mathrm{MJ} / \mathrm{kg}$, determined by the total collection method.

Table 2. Digestibility (\%) of organic matter (OM), metabolizability ME/GE (ME), crude protein (CP), NDF, ADF, hemicelluloses (HEM), crude fiber (CF) and crude ash (ASH) determined by total collection method

\begin{tabular}{|c|l|l|l|l|l|l|l|l|}
\hline diet & OM & ME & CP & NDF & ADF & HEM & CF & ASH \\
\hline $13.4 \mathrm{MJ} / \mathrm{kg}$ & & & & & & & & \\
\hline- & 0.835 & 0.838 & 0.744 & 0.355 & 0.298 & 0.433 & 0.878 & 0.480 \\
\hline+ & 0.813 & 0.815 & 0.724 & 0.271 & 0.089 & 0.454 & 0.759 & 0.464 \\
\hline $\mathrm{p}$ & 0.280 & 0.318 & 0.385 & 0.262 & 0.066 & 0.745 & 0.072 & 0.698 \\
\hline $13.0 \mathrm{MJ} / \mathrm{kg}$ & & & & & & & & \\
\hline- & 0.775 & 0.775 & 0.653 & 0.160 & -0.032 & 0.378 & 0.824 & 0.259 \\
\hline+ & 0.828 & 0.826 & 0.745 & 0.374 & 0.223 & 0.543 & 0.835 & 0.512 \\
\hline $\mathrm{p}$ & 0.005 & 0.005 & 0.005 & 0.022 & 0.048 & 0.024 & 0.646 & 0.003 \\
\hline $12.6 \mathrm{MJ} / \mathrm{kg}$ & & & & & & & & \\
\hline- & 0.747 & 0.759 & 0.648 & 0.143 & 0.138 & 0.152 & 0.840 & 0.312 \\
\hline+ & 0.793 & 0.797 & 0.716 & 0.325 & 0.233 & 0.454 & 0.849 & 0.414 \\
\hline $\mathrm{p}$ & 0.300 & 0.333 & 0.249 & 0.113 & 0.401 & 0.062 & 0.871 & 0.288 \\
\hline \multicolumn{7}{|c|}{ Probability } \\
\hline diet & 0.036 & 0.040 & 0.135 & 0.389 & 0.331 & 0.043 & 0.716 & 0.059 \\
\hline enzymes & 0.115 & 0.142 & 0.034 & 0.037 & 0.429 & 0.005 & 0.219 & 0.006 \\
\hline d*e & 0.119 & 0.116 & 0.089 & 0.310 & 0.014 & 0.109 & 0.094 & 0.025 \\
\hline
\end{tabular}


Table 3. Digestibility (\%) of organic matter (OM), metabolizability ME/GE (ME), crude protein (CP), NDF, ADF, hemicelluloses (HEM), crude fiber (CF) and crude ash (ASH) determined by partial collection method

\begin{tabular}{|c|c|c|c|c|c|c|c|c|}
\hline diet & $\mathrm{OM}$ & AME & $\mathrm{CP}$ & NDF & ADF & HEM & $\mathrm{CF}$ & $\mathrm{ASH}$ \\
\hline \multicolumn{9}{|l|}{$13.4 \mathrm{MJ} / \mathrm{kg}$} \\
\hline- & 0.777 & 0.743 & 0.660 & 0.132 & 0.058 & 0.233 & 0.837 & 0.298 \\
\hline+ & 0.779 & 0.744 & 0.671 & 0.140 & -0.074 & 0.354 & 0.722 & 0.363 \\
\hline $\mathrm{p}$ & 0.893 & 0.956 & 0.641 & 0.859 & 0.034 & 0.152 & 0.055 & 0.181 \\
\hline \multicolumn{9}{|l|}{$13.0 \mathrm{MJ} / \mathrm{kg}$} \\
\hline- & 0.750 & 0.711 & 0.608 & 0.061 & -0.130 & 0.308 & 0.799 & 0.167 \\
\hline+ & 0.754 & 0.721 & 0.637 & 0.106 & -0.100 & 0.335 & 0.826 & 0.305 \\
\hline $\mathrm{p}$ & 0.751 & 0.536 & 0.230 & 0.241 & 0.738 & 0.688 & 0.424 & 0.017 \\
\hline \multicolumn{9}{|l|}{$12.6 \mathrm{MJ} / \mathrm{kg}$} \\
\hline- & 0.701 & 0.683 & 0.565 & -0.004 & -0.012 & 0.012 & 0.814 & 0.195 \\
\hline+ & 0.750 & 0.712 & 0.651 & 0.160 & 0.034 & 0.337 & 0.823 & 0.268 \\
\hline $\mathrm{p}$ & 0.300 & 0.275 & 0.195 & 0.035 & 0.688 & 0.018 & 0.841 & 0.273 \\
\hline \multicolumn{9}{|c|}{ Probability } \\
\hline diet & 0.033 & 0.010 & 0.120 & 0.191 & 0.106 & 0.045 & 0.370 & 0.018 \\
\hline enzymes & 0.266 & 0.231 & 0.075 & 0.017 & 0.709 & 0.003 & 0.280 & 0.005 \\
\hline $\mathrm{d}^{*} \mathrm{e}$ & 0.479 & 0.562 & 0.372 & 0.079 & 0.288 & 0.051 & 0.049 & 0.528 \\
\hline
\end{tabular}

Exogenous enzymes had no effect on digestibility of crude fat in diets with normal energy density as well as in diet with reduced ME. This finding is consitant with the results of other authors (Saleh et al., 2005; Marsman et al., 1997).

The digestibility of NDF, hemicelluloses and crude ash was significantly improved by the supplementation with exogenous enzymes determined by both methods, while digestibility of crude protein was significantly improved by enzymes determined by total collection method. The improvement in digestibility of crude protein is well know (Zanella et al., 1999; Mushtaq et al., 2008; Cantor et al., 2009). Enzymes need to cleave only a few places in polysaccharide chain to grate the reduction of viscosity and enhance digestibility by softening "cage effect" made by NSP in intestines.

The digestibility of ash is not usually common approach, it most often keeps track of digestibility of calcium or phosphor. However, some authors still express digestibility through ash and in works of these authors the usage of multicarbohydrase is accompanied by the increase in digestibility (Saleh et al., 2005).

NDF and hemicelluloses, fraction which are under direct impact of enzymes supplementation, had a significant improvement in digestibility after enzymes supplementation in all treatments, this is consistent with the date from the study by Vranjes (1994), Cantor et al. (2009) and Nian et al. (2011). 


\section{Conclusion}

Reducing of metabolizable energy level caused decrease in digestibility of nutrients and metabolizability (ME/GE). Results suggest that exogenous enzymes, used in this trial, increase digestibility of crude proteins, NDF, hemicelluloses and ash $(p<0.05)$, but the usefulness were most evident in diets with the reduce level of metabolic energy.

\section{Acknowledgment}

Research was financed by the Ministry of Education and Science, Republic of Serbia, project TR 031033.

\section{Efekat egzogenih enzima $u$ ishrani brojlera na svarljivost $i$ metaboličnost u smešama sa različitim nivoom metaboličke energije}

D. Glamočić, M. Polovinski-Horvatović, M. Ivković, D. Beuković, S. Bjedov

\section{Rezime}

U ovom $3 \times 2$ faktorijalnom ogledu, dizajniranom sa tri nivoa metaboličke energije $(13,4,13,00,12,6 \mathrm{MJ} / \mathrm{kg})$, sa $\mathrm{i}$ bez dodataka egzogenih enzima (metabolička energija smeša smanjivana je dodavanjem suncokretove sačme u različitom procentu $(0,8 \mathrm{i} 16 \%)$ cilj nam je bio da ispitamo efekat egzogenih enzima Roxazyme G2G (celulaze (endo-1,4- $\beta$-glukanaza), $\beta$-glukanaze (endo$1,3(4)-\beta$-glukanaze) i ksilanaze (endo-1,4- $\beta$-ksilanaze )) na svarljivost hranljivih materija i metaboličnost. Efekat enzima je bio najuočljiviji u smeši sa $13,00 \mathrm{MJ} / \mathrm{kg}$ i $12,6 \mathrm{MJ} / \mathrm{kg}$, dok je kod smeše sa $13,4 \mathrm{MJ} / \mathrm{kg}$ efekat izostao. Smanjenje metaboličke energije uzrokovalo je smanjenje svarljivosti i metaboličnosti. Rezultati ukazuju da enzimi, korišćeni u ovom ogledu, povećavaju svarljivost sirovih proteina, NDF, hemiceluloze i pepela $(p<0,05)$, ali efekat je bio najizraženiji u smešama sa smanjenom metaboličkom energijom.

\section{References}

BEDFORD M. R. (2000): Exogenous enzymes in monogastric nutrition-their current value and future benefits. Animal Feed Science and Technology, 86, 1, 1-3. 
BEDFORD M.R., APAJALAHTI J. (2001): Microbial interaction in the response to exogenous enzyme utilization. In BEDFORD M.R., PARTRIDGE G.G. (ed.), Enzymes in farm animal nutrition. CABI Publishing, Wallingford, United Kingdom, 299-315.

CANTOR A.H., PESCATORE A.J., FORD M.J., PIERCE J.L., DAWSON K.A. (2009): Effect of enzyme supplementation and acidficiation of diets on nutrient digestibility and growth performance of broiler chicks. Poultry Science, 88, 111-117. CLASSEN H.L., CAMPBELL G.L., RASSNAGEL B.G., BHATTY R.S., REICHERT R.D. (1985): Studies on the use of hulless barley in chick diets: deleterious effects and methods of alleviation. Can. J. Anim. Sci., 65, 725-733.

DOURADO L.R.B., SAKOMURA N.K., BARBOSA N.A.A., BONATO M.A., KAWUAUCHI I.M., FERNANDES J.B.K., COSTA F.G.P. (2009): Corn and soybean meal metabolizable energy with the addition of exogenous enzymes for poultry. Rev. Bras. Cienc. Avic..11, 1, 51-55.

FUENTE J.M., PEREZ DE AYALA P., VILLAMIDE M.J. (1995): Effect of dietary enzyme on the metabolizable energy of diets with increasing levels of barley fed to broiler. Animal Feed Science and Technology, 56, 45-53.

HASTINGS W.H. (1946): Enzyme supplements to poultry feeds. Poultry Sci., 25, 548-586.

MARSMAN G.J.P., GRUPPEN H., VAN DER POEL A.F.B., KAWAKKLE R.P., VERSTEGEN M.W.A., VORGEN A.G.J. (1997): The effect of thermal processing and enzyme treatments of soybean meal on growth performance, ileal nutrient digestibilities, and chyme characteristics in broiler chicks. Poultry Science 76, 864-872. MUSHTAQ T., SARWAR M., AHMAD G., NUSA M. U., JAMIL, A. (2006): The influence of exogenous multienzyme preparation and graded levels of digestible lysine in sunflower meal-based diets on the performance of young broiler chicks two weeks posthatching. Poult. Sci., 85, 2180-2185.

NIAN F., GUO Y. M., RU Y. J., LI F. D., PÉRON A. (2011): Effect of exogenous xylanase supplementation on the performance, net energy and gut microflora of broiler chickens fed wheat-based diets. Asian-Aust.J.Anim.Sci., 24, 3, 400-406.

OLUKOSI, O. A., COWIESON A. J., ADEOLA O. (2007): Age-related influence of a cocktail of xylanase, amylase, and protease or phytase individually or in combination in broilers. Poult. Sci., 86, 77-86.

SALEH F., OHTSUKA A., TANAKA T., HAYASHI K. (2003): Effect of enzymes of microbial origin on in vitro digestibilities of dry matter and crude protein in soybean meal. Animal Science Journal, 74, 23-29.

SCOTT T.A., SILVERSIDES F.G., CLASSEN H.L., SWIFT M.L., BEDFORD M.R., HALL J.W. (1998): A broiler chick bioassay for measuring the feeding value of wheat and barley in complete diets. Poult. Sci., 77, 449-455.

SENKOYLU N., DALE N. (1999): Sunflower meal in poultry diets: a review. World's Poultry Science Journal, 55, 153-174.

SL. LIST SRJ, br. 20/2000 i 38/2001 
TAVERNARI F.C., ALBINO L.F.T., MORATA RL, DUTRA JÚNIOR W.M., ROSTAGNO H.S., VIANA M.T.S. (2008): Inclusion of sunflower meal, with or without enzyme supplementation, in broiler diets. Rev. Bras. Cienc. Avic, 10, 4, 233-238.

VAN SOEST P.J. (1983): Definition of fibre in animal feeds. In: Recent Advances in Animal Nutrition, Butterworts, London, 71-86.

VOGTMANN H., PFIRTER H.P., PRABUCKI A.L., (1975): A new method of determining metabolisability of energy and digestibility of fatty acids in broiler diets. Brit. Poultry Sci., 16, 531-534.

VRANJES M.V., PFIRTER H.P., WENK C. (1994): Influence of processing treatment and type of cereal on the effect of dietary enzymes in broiler diets. Animal Feed Science and Technology, 46, 261-270.

ZANELLA I., SAKOMURA N. K., SILVERSICLES F. G., FIQUEIRCLO A., PACK. M. (1999): Effect of enzyme supplementation of broiler diets based on corn and soybeans. Poult. Sci. 78, 561-568.

ZHOU Y., JIAN, Z., LV D., WANG T. (2009): Improved energy-utilizing efficiency by enzyme preparation supplement in broiler diets with different metabolizable energy levels. Poult. Sci., 88, 316-322.

Received 30 June 2011; accepted for publication 15 August 2011 